\title{
Unusual complication of colonoscopy
}

\author{
Naveen Voore
}

Department of Internal

Medicine, Riverside Shore

Memorial Hospital,

Nassawadox, Virginia, USA

\section{Correspondence to}

Dr Naveen Voore,

voorenaveen@yahoo.com

Accepted 5 September 2015

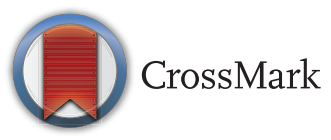

To cite: Voore N. BMJ Case Rep Published online:

[please include Day Month

Year] doi:10.1136/bcr-2015-

212274

\section{DESCRIPTION}

A 52-year-old woman presented with left upper quadrant abdominal pain. She was discharged from the outpatient surgical unit after she had screening colonoscopy. On presentation, her vitals were normal. She was found to have tenderness in the left upper quadrant. Initial X-ray of the abdomen did not reveal free air, but a subsequent CT scan of the abdomen showed haemoperitoneum and splenic haematoma (figure 1). The patient was taken to surgery and underwent splenectomy.

Splenic injury due to colonoscopy is a rare complication. The most common reason for splenic injuries during colonoscopy are due either to trac-

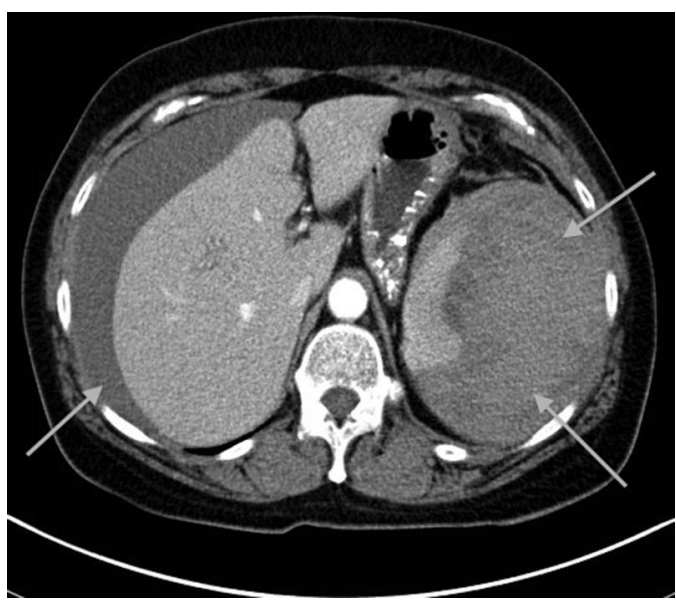

Figure 1 Axial view of CT of the abdomen shows haemoperitoneum and splenic haematoma (marked with grey arrows). tion on the splenocolic ligament or excess manipulation during the procedure to advance the scope beyond the splenic flexture. ${ }^{1}$ Abdominal pain is the most common symptom but can also present with anaemia and leucocytosis. CT is the investigation of choice to evaluate the extent of injury. Treatment options include either observation alone or splenectomy; options are considered based on haemodynamic status and the size of the haematoma. There have been case reports describing treatment with splenic artery embolisation. Also, newer methods such as wrapping vicryl netting around the spleen can be considered; these have been successfully performed. ${ }^{2}$

\section{Learning points}

- Splenic haematoma is a rare and unusual complication after colonoscopy.

- Abdominal pain after colonoscopy should raise suspicion for splenic haematoma and other complications.

Competing interests None declared.

Patient consent Obtained.

Provenance and peer review Not commissioned; externally peer reviewed.

\section{REFERENCES}

1 Castelli M. Splenic rupture: an unusual late complication of colonoscopy. CMAJ 1986;134:916-17.

2 Schilling D, Kirr H, Mairhofer C, et al. Splenic rupture after colonoscopy. Dtsch Med Wochenschr 2008;133:833-5.

\footnotetext{
Copyright 2015 BMJ Publishing Group. All rights reserved. For permission to reuse any of this content visit http://group.bmj.com/group/rights-licensing/permissions.

BMJ Case Report Fellows may re-use this article for personal use and teaching without any further permission.

Become a Fellow of BMJ Case Reports today and you can:

- Submit as many cases as you like

- Enjoy fast sympathetic peer review and rapid publication of accepted articles

- Access all the published articles

- Re-use any of the published material for personal use and teaching without further permission

For information on Institutional Fellowships contact consortiasales@bmjgroup.com

Visit casereports.bmj.com for more articles like this and to become a Fellow
} 